Acta vet. scand. $1964,5,7-16$.

From the Royal Veterinary College and the Geological Survey of Sweden, Stockholm.

\title{
DETERMINATION OF ZINC IN PIG BLOOD
}

\author{
By
}

I. Månsson, M. Askling and F. Manheim

The presence of zinc in living organisms and its role as an essential nutrient has long been known. For a review of pertinent literature in this field the reader is referred to Vallee (1959). Tucker and Salmon (1955) demonstrated that zinc has both a therapeutic as well as a preventative effect on swine parakeratosis. Hoekstra et al. (1956) investigated blood zinc in parakeratotic pigs. The material was limited but a decrease in zinc content in the blood plasma of the afflicted pigs seemed to be indicated. The zinc content of a number of organs in which zinc is known to occur in a functionable form was not significantly altered. The last mentioned observation was confirmed by Grünberg (1961), who also noted relatively high zinc values in the liver of parakeratotic pigs. Because of the lack of investigations on blood zinc in parakeratotic pigs it is difficult to evaluate the concept that a diminished resorption of zinc from the intestines is characteristic for the affected animals. This question is important, especially since many investigators have reported parakeratosis to be a zinc deficiency disease of unknown origin.

In the course of studies on the effects of diet on the microbial flora of the intestinal tract the present writers noted that under certain conditions experimental animals developed parakeratosis (Månsson and Olsson 1961). At an early stage in the sickness, when the pigs had developed skin lesions but had not yet lost 
appetite, urine was investigated for zinc by means of the dithizone test described by Huff (1948). It was found that in affected pigs zinc was undetectable or present in very small amounts, whereas in symptom-free control animals which had received a proteinpoorer diet zinc was present in easily detectable quantities. These observations led to the examination of blood.

In the past, study of zinc in blood has been attended by some methodological difficulties; these are accentuated by the fact that zinc is an ubiquitous contaminant in the laboratory, so that determination of the small amounts present in blood requires a fastidious laboratory technique. The colorimetric procedure for zinc as outlined by Vallee and Gibson (1948), Hoch and Vallee (1949), Vikbladh (1950) and others offers high sensitivity and with careful attention to detail, a good precision. Spectrochemical determination of zinc in blood was described by Monacelli et al. (1956), working at the University of Virginia. A.D.C. arc method using the zinc resonance line 2138 was employed. An improved method was reported by workers at the same laboratory (Paixao and Yoe, 1959), utilizing $\mathrm{Zn} \mathrm{3345.} \mathrm{It} \mathrm{should} \mathrm{be} \mathrm{noted} \mathrm{that} \mathrm{these}$ workers used a relatively large amount of blood, $50 \mathrm{ml}$. - a necessary condition to obtain sufficient sensitivity with the rather insensitive $\mathrm{Zn} 3345$ line.

In the present case a solution spectrographic technique developed at the Geological Survey of Sweden for sediments, soils and peat offered promise of adequate precision, reduced requirements for purified chemicals and glassware and good adaptability to serial determinations. The shorter time requirement than previously described quantitative techniques was decisive in favour of adoption of the spectrochemical procedure.

With only $1 \mathrm{ml}$. of blood available in the present case the zinc lines (I) 3345 , (II) 2505 and (II) 2558 proved insufficiently sensitive and use of (I) 2138 was necessary. Due to its marked self-absorption this line is notoriously difficult to work with in the $\left.\operatorname{arc}^{1}\right)$. However, in the high voltage spark the above difficulty falls away and with a capillary solution electrode reproducible excitation could be achieved.

1) Eastmond and Williams (1948) took advantage of the broadening of $\mathrm{Zn} 2138$ in the $\mathrm{AC}$ arc to elaborate a line width method for $\mathrm{Zn}$ in plant ash. 


\section{ANALYTICAL PROCEDURE}

\section{Mineralization of blood and sample preparation}

Reagents:

$\mathrm{HNO}_{3}$ "Lead free" British Drug Houses

$\mathrm{H}_{2} \mathrm{O}$ single distilled in all Pyrex still

$\mathrm{NaCl}$ Johnson-Matthey SpecPure

CdO Baker Analytical Reagent

$\mathrm{ZnO}$ Merck Pro Analysi

$1 \mathrm{ml}$. of blood was pipetted into $20-30 \mathrm{ml}$. platinum crucibles, $0.5 \mathrm{ml}$. concentrated $\mathrm{HNO}_{3}$ added, and the mixture evaporated to dryness on an electric hotplate. The crucibles were then placed in an electric oven at $550^{\circ} \mathrm{C}$ for 90 minutes to ash the organic matter. After this time $1 \mathrm{ml}$. concentrated $\mathrm{HNO}_{3}$ was added to the residue and evaporated to dryness on the electric hotplate. At this stage colorless crystalline residues were obtained. A bufferinternal standard solution consisting of $0.5 \mathrm{M}$. NaCl and $20 \mathrm{mg} . / \mathrm{l}$. $\mathrm{CdO}$ in $1 \mathrm{M} . \mathrm{HNO}_{3}$ was prepared. The residue was dissolved in $1 \mathrm{ml}$. buffer-internal standard solution and transferred to small pyrex test tubes. Completely quantitative transfer is not necessary since internal standard is incorporated.

For standards $\mathrm{ZnO}$ was dissolved in $1 \mathrm{M}$. $\mathrm{HNO}_{3}$ to double the desired concentrations of $1,2.5,5$ and $10 \gamma / 1$. These standards covered the normal range of $Z_{n}$ in the blood types investigated. The standards were then mixed 1:1 with the above buffer-internal solution in double strength. Solutions identical in cadmium and buffer concentrations were thus obtained.

\section{SPECTROGRAPHIC PROCEDURE}

Solutions were transferred to teflon or nylon "vacuum cups" of capillary electrodes modelled after Zink (1959), modified to a narrow annulus holding only $0.2 \mathrm{ml}$. solution. Fig. 1 shows the electrodes. A prespark (about 5 seconds) is given until the solution rises to the sparking surface. Following a 40 second exposure the cup is refilled and an additional 40 second exposure given on the same spectrum. About $0.15 \mathrm{ml}$. liquid is consumed in 40 seconds. A 40 second exposure gave sufficient sensitivity with Kodak SWR plate, but 80 seconds were necessary to bring up density of the $\mathrm{Zn}$ line into a range permitting accurate photometering when the less expensive and more easily handled B-10 emulsion was utilized. Standards were run on each plate. 


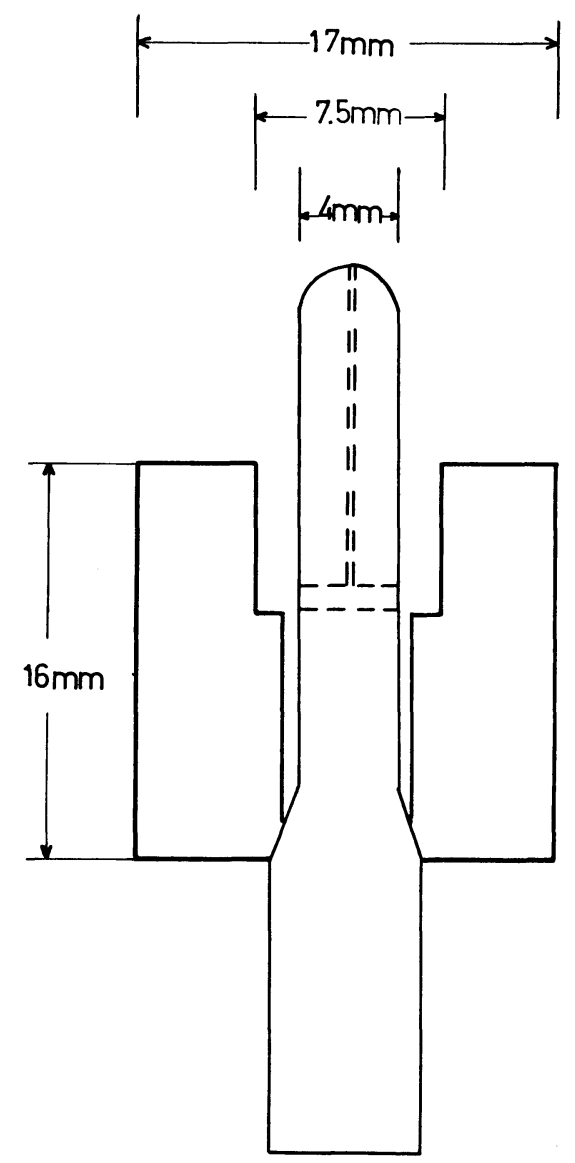

A

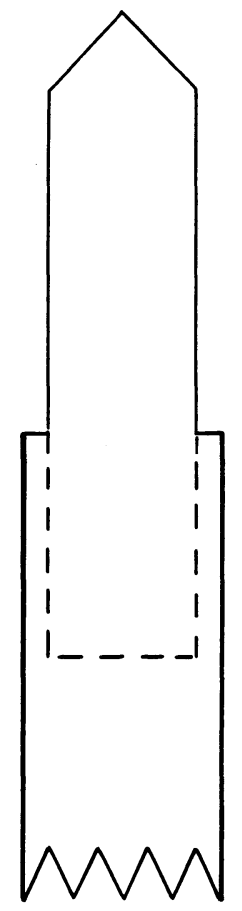

B

F i g. 1. Capillary electrodes. A shows graphite electrode with cup seated on shoulder. Transverse hole $1.5 \mathrm{~mm}$, capillary hole $0.7 \mathrm{~mm}$ diameter. B shows counterelectrode in stainless steel holder. Electrode diameter is $6.35 \mathrm{~mm}(1 / 4 ")$.

Data for solution spark technique

Spectrograph Zeiss Q-24 medium quartz; dispersion ca. $5 \AA / \mathrm{mm}$. at $2140 \AA$.

Optical data Three lens even illumination with $4 / 20 / 100 \%$ transmission optical filter before $15 \mu$ slit.

Excitation Hilger Source Unit, $15 \mathrm{kv}$ spark, $0.01 \mathrm{mH}$ inductance plus residual, no damping or added resistance. 


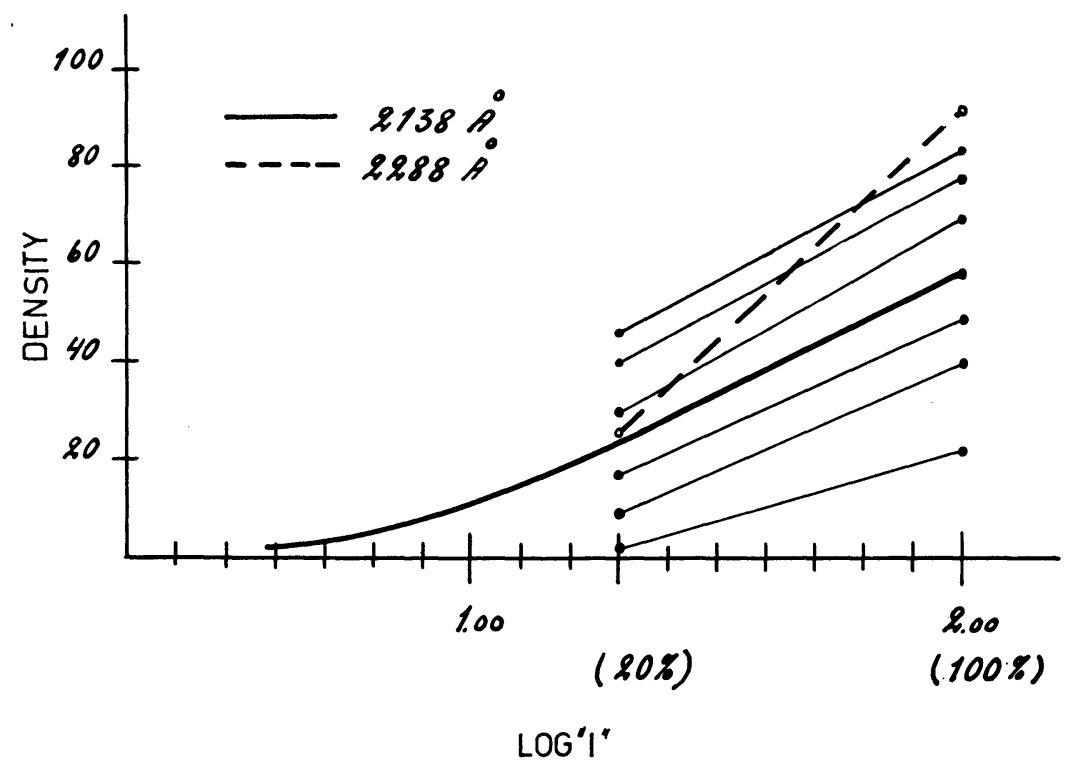

F i g. 2. Emulsion calibration curve for Kodak B-10. The curve is prepared by plotting two filter steps for each of a number of lines. Starting at a given line the segments are shifted so that the higher step falls on the given line; the lower step then forms a point on the continuation of the curve toward the toe.

Electrodes Ringsdorff RW IV (standard quality) graphite, capillary boring $0.7 \mathrm{~mm}$.

Registration Kodak B-10 plate, developed 5 min. at $26^{\circ} \mathrm{C}$ in Kodak D-19. Fixing and wash water kept at same temperature.

Evaluation Zeiss (Jena) Schnellphotometer. Calibration curve by 2 step line shifting method (Fig. 2 ). Line pair Zn 2138/Cd 2288.

\section{DISCUSSION OF METHOD}

One point subject to conflicting statements in the literature is the loss of zinc on ignition ${ }^{1}$ ). Thiers (1957), referring to results by Bambergs states that zinc is lost at temperatures over $450^{\circ} \mathrm{C}$, whereas Kägi and Vallee (1958) found loss of zinc at tempera-

1) See Middleton and Stuckey (1953) for detailed references on ashing techniques and problems. 


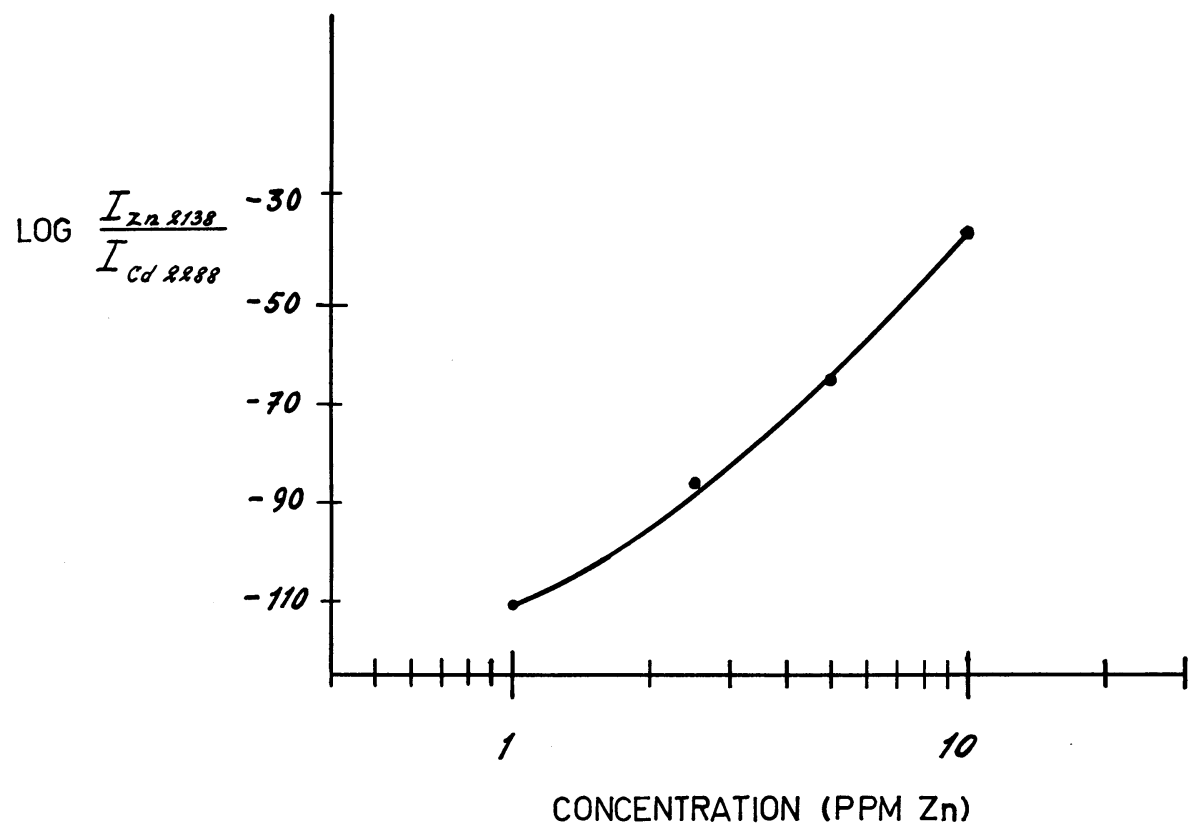

Fi g. 3. Typical working curve.

tures below $550^{\circ} \mathrm{C}$, but no loss at $550^{\circ} \mathrm{C}$. Vikbladh (1950) also found no losses of zinc added to serum which was ignited for 20 hours at $600^{\circ} \mathrm{C}$. Although this applied strictly only to the added (inorganic) zinc, the fact that she obtained similar results both by ignition and by a modification of the trichloracetic acid precipitation method suggests that losses of organic zinc, if any, should be small. Our checks with samples of blood prepared both by wet and dry ashing have not yet reached conclusive results.

A series of 9 one ml. portions of a blood sample was processed in the regular manner, including separate ashing. The spread of the results, expressed as a standard of deviation, was $9 \%$. A part of the scatter may be ascribed to the necessity of working near the wavelength limit of effectiveness for the B-10 plate. Separate calibration curves were necessary for $\mathrm{Cd}$ and $\mathrm{Zn}$, the difference in plate gamma being illustrated in Fig. 2. A working curve is shown in Fig. 3. An iron line, Fe 2138.6 coincides with $\mathrm{Zn} 2138.6$ but is weak in the spark and is not visible at the iron levels encountered in blood. A weak copper interference line is also absent. Copper was detectable in the spectra, and if desired may be conveniently determined by means of the line pair (II) 
$\mathrm{Cu} \mathrm{2247/(II)} \mathrm{Cd} \mathrm{2265.} \mathrm{Purity} \mathrm{of} \mathrm{the} \mathrm{HNO}_{3}$ and reference solution was checked spectrographically, while dithizone was used to check the distilled water. Platinum crucibles and glassware were cleaned by boiling in $\mathrm{HNO}_{3}$ and washing with distilled water.

\section{EXAMINATION OF WHOLE BLOOD FROM PIGS}

As an example of results gained with the above method studies on two groups of non-parakeratotic pigs are shown here. More extensive results including afflicted pigs will be presented later.

Pigs on a relatively protein-poor diet do not generally develop parakeratosis. The animals also remain symptomfree if a proteinrich fodder is given wet while pigs on such a fodder given dry in a self-feeder may develop the diesease (Månsson and Olsson 1962). To get an idea of the influence of the fodder on blood zinc values two groups of pigs consisting of 3 pigs each were tested. Average age at the beginning of experiments was 11 weeks, and weight was $19-23 \mathrm{~kg}$. Group I was self-fed a diet of $85 \mathrm{~g}$. digestible protein per Scandinavian Feed Unit (SFU), 6.8 g. Ca and $4 \mathrm{~g}$. $\mathrm{P}$ per $\mathrm{kg}$. fodder. The pigs had free access to drinking water and no bedding was used in the pens. The diet of Group II contained $14 \%$ fish meal which gave $146 \mathrm{~g}$. digestible protein per SFU, $15.5 \mathrm{~g}$. Ca and $9.4 \mathrm{~g}$. $\mathrm{P}$ per $\mathrm{kg}$. fodder. The group was fed twice a day, the dry meal being mixed 2:3 with drinking water immediately prior to feeding. Amount of fodder per day was the same in both cases.

T a b l e 1. Blood zinc values in p.p.m.

$\begin{array}{lcccrr}\begin{array}{l}\text { No. of exp. days } \\ \text { Group I. }\end{array} & 1 & 14 & 26 & 36 & 48 \\ \begin{array}{l}\text { Pig no. } \\ \text { A }\end{array} & & & & & \\ \text { B } & 7.0 & 5.2 & 5.3 & 8.0 & 10.7 \\ \text { C } & 6.1 & 4.8 & 6.5 & 8.0 & 6.5 \\ \end{array}$

Group II.

Pig no.

$\begin{array}{llllll}\mathrm{D} & 6.4 & 4.5 & 6.1 & 6.0 & 7.0 \\ \mathrm{E} & 5.6 & 4.1 & 7.1 & 5.4 & 7.2 \\ \mathrm{~F} & 6.2 & 4.1 & 6.4 & 4.3 & 6.9\end{array}$

Blood samples were taken the first, 14th, 26th, 36th and 48th days and the values obtained are shown in Table 1. As may be 
seen all pigs showed a diminished level of blood zinc on the 14th day, independent of diet. In no case did the individual animal reach lower values at any time during the experiment. In view of the small sampling and relatively large individual variations no average has been calculated. Comparison of the present whole blood values with literature data calculated from plasma and erythrocyte figures is also uncertain. Earlier experiments have repeatedly shown that the pigs develop the strongest signs of parakeratosis if they fall ill a couple of weeks after the beginning of the experiment, at an age of 10-14 weeks. No extensive conclusions may be drawn from the present material. However, the pigs had a lower blood level of zinc at the time they are most susceptible to parakeratosis. Further studies are indicated to confirm this statement.

\section{REFERENCES}

Eastmond, E. J. and Williams, B. E.: Wide range analysis for zinc using spectrographic line widths. J. Optical Soc. Amer. 1948, $38,800-803$.

Grünberg, W.: Untersuchungen über den Schwermetallgehalt (Kupfer, Zink, Mangan) der Organe, des Blutes und der Milch beim Schwein. Arck. Exp. Veterinärmedizin 1961, 15, 828-867.

Hoch, F. L. and Vallee, B. L.: Precipitation by trichloroacetic acid as a simplification in the determination of zinc in blood and its components. J. Biol. Chem. 1949, 181, 295-306.

Hoekstra, W. G., Lewis, Jr., P. K., Phillips, P. H. and Grummer, R. H.: The relationship of parakeratosis, supplemental calcium and zinc to the zinc content of certain body components of swine. J. Animal Sci. 1956, 15, 752-764.

Huff, L. C.: A sensitive field test for heavy metals in water. Economic Geology 1948, 43, 675-684.

Kägi, J. H. R. and Vallee, B. L.: Determination of zinc by direct extraction from urine with diphenylthiocarbazone. Anal. Chem. 1958, 30, 1951-1954.

Middleton, G. and Stuckey, R. E.: Preparation of biological material from metals. I. A critical review of existing procedures. Analyst 1953, 78, 532-542.

Monacelli, R., Tanaka, H. and Yoe, J. H.: Spectrochemical determination of magnesium, chromium, nickel, copper and zinc in human plasma. Clin. Chim. Acta 1956, 1, 577-582.

Månsson, I. and Olsson B.: The intestinal flora of pigs. I. Quantitative studies of coliforms, enterococci, and clostridia in the faeces of pigs self-fed a high-protein and high-calcium diet. Acta agric. Scand. 1961, XI, 197-210. 
Månsson, I. and Olsson, B.: Idem. II. Further quantitative studies of coliforms, enterococci, and clostridio in the faeces of pigs self-fed a high-protein and high-calcium diet. Acta agric. Scand. 1961, XI, 257-264.

Månsson, I. and Olsson, B.: Idem. VI. Quantitative studies of coliforms, enterococci, and clostridia in the faeces of pigs fed a high animal protein and calcium diet and determination of histamine and histaminase activity in the blood. Acta agric. Scand. 1962, $X I I, 344-354$.

Månsson, I.: Idem. VII. Urinary histamine levels and coliforms, enterococci, and clostridia in the faeces of pigs fed a high protein diet. Acta agric. Scand. 1963. In press.

Paixao, L. M. and Yoe, J. H.: Spectrochemical determination of magnesium, chromium, nickel, copper and zinc in human plasma and red cells. Clin. Chim. Acta 1959, 4, 507-514.

Tucker, H. F. and Salmon, W. D.: Parakeratosis or zinc deficiency disease in pig. Proc. Soc. Exp. Biol. Med. 1955, 88, 613-616.

Thiers, R. E.: Separation, concentration, and contamination, pp. 637666 in Yoe, J. H. and Roch, Jr., H. J.: Trace analysis. Symposium Trace Anal. N. Y. Acad. Med. 1955 (Pub. 1957), 672 pp.

Vallee, B. L.: Biochemistry, physiology and pathology of zinc. Phys. Rev. 1959, 39, 443-490.

Vallee, B. L. and Gibson, 2nd, J. G.: An improved dithizone method for the determination of small quantities of zinc in blood and tissue samples. J. Biol. Chem. 1948, 176, 435-443.

Vikbladh, I.: Studies on zinc in blood. I. Scand. J. Clin. Lab. Invest. $1950,2,143-148$.

Zink, T. H.: Vacuum cup electrode for the spectrochemical analysis of solutions. Appl. Spectroscopy 1959, 13, 94-97.

\section{SUMMARY}

A rapid spectrochemical method for determining zinc in $1 \mathrm{ml}$. portions of pig blood is described. Blood ash is dissolved in $\mathrm{HNO}_{3}$ and excited in a high voltage spark, using graphite capillary electrodes. Spectra are recorded on Kodak SWR or B-10 plates and the analysis (internal standard line pair $\mathrm{Zn} \mathrm{2138/Cd} \mathrm{2288)} \mathrm{is} \mathrm{densitometered.}$

Some results for young pigs fed on both wet and dry diet show a period of low blood zinc about 13 weeks after birth, coinciding with maximum susceptibility to swine parakeratosis.

\section{ZUSAMMENFASSUNG}

Bestimmung des Zinkhaltes in Schweineblut.

Der Zinkhalt im Blut ist mit einer spektrochemischen Methode bestimmt worden. Kleine Mengen Blut - $1 \mathrm{ml}$ - wurden verwendet. Das eingeäscherte Blut wird in $\mathrm{HNO}_{3}$ gelöst mit dem Zusats von Kadmium als Referenz. Die Spektralaufnahme geschieht im Hochspan- 
nungsfunken und Spektra werden auf Kodak B-10 Platten registriert. Standardproben werden auf jeder Platte aufgenommen. Die Analyse wird photometriert.

Untersuchungen über den Blutzinkhalt bei Schweinen in einem begrenzten Material von eiweissreicher und eiweissarmer Kost sind beschrieben.

\section{SAMMANFATTNING}

Bestämning av zinkhalten $i$ helblod från gris.

Zinkhalten i blod har bestämts med en spektrokemisk metod. Små volymer blod - $1 \mathrm{ml}$. — har använts. Det inaskade blodet löses $\mathrm{i}^{\mathrm{HNO}_{3}}$ med tillsats av kadmium som referens. Spektralupptagningen sker $i$ högspänningsgnista och spektra registreras på Kodak B-10 plåtar. Standardprov upptages på varje plåt. Analysen fotometreras.

Undersökningar över blodzinkhalten hos grisar i ett begränsat material på äggviterik och äggvitefattig utfodring redovisas.

(Received May 14. 1963). 